\title{
Bioenergy, Thermodynamics and Inequalities
}

\author{
Larry Lohmann
}

\subsection{Introduction}

This chapter takes a step back from the empirically detailed studies of the bioenergy boom in Latin America, Asia and Europe that comprise the bulk of this book in order to focus on some of the underlying historical dynamics of bioenergy. It does so out of the conviction that only an activism that takes account of the exploitation and appropriation common to specific instances of bioenergy development is likely to be effective in the long term against the degradations and threats to survival that it entails.

The chapter concentrates mainly on the contradictions of the thermodynamic energy developed in the nineteenth century as a background for sketching how bioenergy perpetuates and accentuates these contradictions, and what the consequences are for biofuel developers, energy

L. Lohmann $(\bowtie)$

The Corner House, Sturminster Newton, UK e-mail: larrylohmann@gn.apc.org 
transition enthusiasts and bioenergy critics. Interleaved with this exposition are reflections on how social movements might place themselves more strategically in bioenergy struggles.

\subsection{Thermodynamic Energy as Politics}

There is little point in studying bioenergy without some idea of what it is. Clearing away some common confusions, anachronisms and teleologies is crucial at the start.

The biggest confusions are around energy itself, not just bioenergy. These confusions can be found in the writings of many respected contemporary historians such as E. A. Wrigley (2010), Rolf Sieferle (2010), J. R. McNeill (Steffen et al. 2011), Kenneth Pomeranz (2000) and Vaclav Smil (2017). Such writers tend to assume lazily that every society in history has possessed fundamentally the same hunger for greater and greater supplies of an item they call "energy". They seldom define this item or inquire into its history. For example, Wrigley (2010, pp. 42, 44, 191, 205), Sieferle (2010, p. 137) and McNeill (in Steffen et al. 2011, p. 848) each write that an energy "bottleneck" in pre-industrial societies frustrated an intrinsic, pan-human desire for growth - a bottleneck that was only broken with the advent of the fossil fuel era in nineteenth-century Europe.

But there was no such bottleneck (Malm 2016). There was no such energy. The practice and theory of energy, energy stocks and energy sources that we take for granted today did not exist before 1800. At that time, no extensive industrial conversion and transfer infrastructure existed that was capable of uniting and commensurating various thermal, dynamical, electrical and other phenomena into the unitary, indestructible, abstract force that only later came to be called "energy". It was not yet possible even to think about disentangling muscular exertion, wood burning and falls of water (say) from the diverse social or natural contexts in which they were embedded, re-entangle them into systems of exchangeable "equivalents", and accumulate the transformed result into a single pile. Before then, as historian Joel Mokyr (1999, pp. 20-21) observes, "the notion that a horse pulling a treadmill and a coal fire 
heating a lime kiln were in some sense doing the same thing would have appeared absurd". None of these things were "energy consumption". Energy had neither use-values nor exchange value because there was nothing identifiable as such to be valued. There were no "energy companies". There was no "energy sector", no "energy outlook", no "energy planning", no "energy transition", nor any "energy alternatives". It would have been hard to explain units of measurement like joules, BTUs, kilogramme-metres, ergs, dynes, calories, therms, newtons or barrels of oil-equivalent. Concepts such as "energy return on investment" (EROI) would have been incomprehensible. Although steam engines were already being used early in the eighteenth century for specialized purposes (indeed there had been toy steam engines in ancient Greece), they had not yet begun converting the latent heat of coal stocks into mechanical energy on a scale sufficient to restructure whole industrial, transport and shipping systems. The electric batteries first described in 1800 , which transform chemical energy into electrical energy and back, were as yet only a curiosity. Dynamos for converting mechanical energy into electricity did not exist until 1830 or become industrially significant until the 1870s. Electric motors for converting electricity back into mechanical energy appeared only in the 1830s and were embedded into industry only in the 1890s. It was only in the mid-nineteenth century, similarly, that the telegraph began to entrench the mutual convertibility of electricity and magnetism into everyday experience worldwide. Solar cells that could convert sunlight to electricity were not built until 1839. Internal combustion engines for converting chemical to thermal to mechanical energy, although conceived before 1800 , began to be marketed only in the 1860 s and 1870 s.

Correspondingly, it was only between around 1820 and 1850 that today's concept of energy (if anything that remains so incoherent can be called a concept) began to take shape via thermodynamics (see Thermodynamics: The First and Second Laws). Thermodynamics developed principally out of the project of a certain privileged group of male Northern Europeans to theorize industrial heat engines (Daggett 2019, p. 37). It was impelled largely by the need to help machines provide business with labour productivity increases, labour discipline, labour concentrations and relative independence from a multitude of ingrained 
human and more-than-human rhythms, as well as speedier realization of the value of commodities (Malm 2016; Huber 2009). Its "regulative idea" of unified energy also influenced the mapping and organizing of new frontiers for extraction of fuels for capital's conversion devices. To adapt the terminology of Naoki Sakai (1997, p. 41), the growth of energy science, like that of so many other disciplines, was not "determined by the existence of its object". Rather, the object that emerged was "made possible by the existence of the discipline".

\section{Thermodynamics: The First and Second Laws}

In 1865, the great German physicist Rudolf Clausius summarized thermodynamics in two laws:

1. The energy of the universe is constant.

2. The amount of usable energy declines (i.e. entropy tends to increase in a closed system).

The First Law inspired capitalists to try to put the entire universe to work. It conceptualized a monolithic "energy" that was both inexhaustible and interconvertible. Whatever capital needed to make machines run-mechanical force, heat, electricity, magnetism, lightcould be conjured up from any other form of energy that was lying around, given enough ingenuity.

The Second Law revealed the other side of the story. It showed that the more that capital instrumentalized waterfalls, fire, wind, coal, magnetism and so forth as being mere aspects of this great pool of abstract energy, the less of the new energy actually became available for capital's own use. The more that energy was converted back and forth into different forms (Smil 2017, p. 26), the more of it was "degraded". Linear time assumed a new prominence in the shape of an arrow indicating a one-way trip towards universal "heat death".

The contradiction between the two laws reflects the contradictions of the capitalist society that gave rise to them. The First Law helped capital treat the world as a limitless, fungible resource. The Second Law exposed the flip side: waste, pollution and disorder that would ultimately cripple industrial capital itself. 
Yet even after the First Law began to be formulated, energy was still not treated as a single abstract fluid that could be transferred in large quantities over long distances. The first articulations of the Law set up methodologies for calculating equivalences among previously separated domains like motion and heat, but did not mention conservation or transformation of a singular energy. For example, James Joule, the brewing capitalist who in the 1840s struggled to fix a mechanical "equivalent" for heat, "never said that all forces are essentially differing manifestations of the same ontological 'thing" (Mirowski 1989, p. 42). That reification was introduced by Lord Kelvin in 1851. Even at the turn of the twentieth century, textbooks were still presenting the First Law more as a "principle of equivalence" than as the "principle of conservation of energy" (Coelho 2009, p. 2651). To be sure, the latter usage is now the popular one (Mirowski 1989, p. 13). Yet the same energy science that has encouraged the public to fetishize energy as an object has also, paradoxically, continually undermined the fetish. By the 1880 s, for instance, Hermann von Helmholtz found himself "in cautious retreat from the conception of energy as a mechanistic substance" (ibid., p. 47). In 1918, Noether's Theorem, developed by the Göttingen mathematician Emmy Noether, "drove another nail into the coffin of energy as a substance", cementing a sense that "energy was not really any one thing, but rather a flexible means of expressing symmetry principles" (ibid., p. 72). In 1943, the Harvard physicist P. W. Bridgman argued that energy was just too "hybrid" for it to be possible to set up a "parallelism" between it and "ordinary material things" (Bridgman 1943, p. 115). In the 1960s, the Nobel physicist Richard Feynman famously reminded his audience that the First Law had never actually described "anything concrete": "we have no knowledge of what energy is" (Feynman 2010, volume 4, chapter 1). By 2011, it was possible for one prominent thinker to define energy simply as a "relationship of difference that tends to eliminate itself", a "gradient across which there is a tendency to even out and dissipate"that is, as a form rather than a substance (Deacon 2011, pp. 218-219). Nothing could be further from the technocratic picture of energy as a universal fuel with sources dotted around the landscape. Yet in a sense, the conception of energy as form rather than substance has been present from the very beginning of thermodynamics. It derives ultimately from 
the inspired analogy explored by the early nineteenth-century French thermodynamicist Sadi Carnot between the "falls" (chutes) of water that riverside mills captured and the "falls" from hot to cold that made heat engines work (Carnot 1988 [1824]). Although Carnot himself thought of heat as a substance, his metaphor paved the way for a conception of energy that emphasized relations and terrains rather than magical stuff.

Throughout its early development, energy science was created largely by engineers who shared the interests of business. "An economic point of view formed the root of thermodynamics", historian Theodore Porter (1994, p. 141) emphasizes. "Economic and physical ideas grew up together, sharing a common context". As historians of science Crosbie Smith and M. Norton Wise (1989, pp. xx-xxi) note, the mathematical physics of Lord Kelvin was "thoroughly permeated" by an industrial capitalist cosmovision. Nor would energy as we know it have come into being without empire, for which thermodynamics was a welcome way of reorganizing activities belonging to diverse networks of life into a monolithic, unitary "energy"-supporting worldwide deployment of steam engines, vortex turbines and transoceanic cables. Indeed, the emergence of coal as an imperial "fossil fuel" itself played a part in cementing thermodynamic energy into political thinking worldwide. Simply because it was by nature abundant, concentrated, easily transportable and accumulable, usable in a wide variety of contexts, and completely independent of annual plant growth cycles, coal (and later, oil and gas) was an avatar for the kind of "universal energy equivalent" that thermodynamics was already advocating. It was not that there had always existed a primordial panhuman need for more and more abstract "energy" that fortunately just happened to be relieved one day by fossil fuels. Rather, fossil fuels themselves helped shape the idea of such an energy. Of course, for millions of years, long before Homo sapiens came along, processes had been going on that were later described as the transformation of sunlight into thermal energy, thermal and chemical into mechanical energy, mechanical energy into electricity and so forth. None of that began in the nineteenth century. But without post-1800 imperial reorganizations of relations among humans and nonhumans, energy and its ideology could never have become so hegemonic. 
If capital and empire made thermodynamics what it is, thermodynamics fully returned the favour (Daggett 2019). Thermodynamic energy was there to carry out an unlimited amount of what early nineteenth-century Cornwall engineers measured as the "duty" done by given quantities of coal (Cardwell 1993, p. 117). It was pictured as being available to business anywhere on earth or off it. "Energy sources" became geographic features, whether they were rivers with steep drops, coal seams, oil fields, peninsulas with steady high winds, uranium deposits, deserts with high rates of insolation, forests with chippable trees or stretches of soil suitable for oil palm, jatropha or sugar cane. Mapped in this way, energy sources could be made to overlie, overlap or even obliterate other geographical features such as cultivated land, indigenous territories, water sources, grazing grounds or customary property or political boundaries. The abstract energy symbolized in the First Law of Thermodynamics became a real part of the world, entangling itself into the emergent "abstractified" forms of work, society, space, water and nature that to some extent had preceded it on the early modern landscape. Thermodynamics was thus a crucial technique of enclosure of commons across Europe, India, Africa and the Americas. It was also indispensable to the mobilization of millions of newly landless labourers and slaves in centres of mechanization, as well as to the growth of the role of commodity exchange in providing the necessities of life.

Today's thermodynamically rationalized "biofuel complex", for instance, has engendered a new concept of "marginal land" in the tradition of older colonial notions of "waste" and terra nullius. Areas of land identified through remote sensing as "non-competitive" for purposes of industrial food production become acceptable sites for energy extraction on a par with deposits of peat or oil shale. Like the twentieth-century notion of "sacrifice zones" (National Academy of Sciences 1974), this geographic/thermodynamic methodology tends to obscure many other features of the land in question (Nalepa and Bauer 2012). These include not only the capacity to supply medicine, provide building materials and sustain hunting, gathering, grazing and subsistence farming. They also include the plural non-thermodynamic or "little-e" energies (Lohmann and Hildyard 2014) inherent to the territory, maintaining the mutual 
incommensurability of which is often central to local livelihood strategies and resistance to encroachments of big capital and the state.

In addition to augmenting a notion of efficiency that has contributed to modern racism and colonialism (Daggett 2019; Alexander 2008), the energy abstraction has also significantly expanded the domain of global scarcity. Until firewood from a common woodland becomes "energy", it is not necessarily scarce in an economic sense (Lohmann and Hildyard 2014, pp. 63-64). Correspondingly, it is only with thermodynamic energy that modern waste really comes into its own, as well as the types of human labour that are needed to help clean up, stow, reuse, manage, absorb or hide it. Thermodynamic energy is all about putting together diverse Carnotian "falls" or irreversible erosions of difference across broad geographies. As such, it unavoidably generates forms and volumes of "waste" energy specific to the age of the Second as well as the First Laws of Thermodynamics. This is so whether the "falls" in question consist of water sluicing through dam penstocks, air impacting on the blades of windmills, "falls" of electrons through the electrolyte of batteries connected to closed circuits, "falls" from hot to cold within aircraft engines, or "falls" of soil fertility into sterility on industrial biomass plantations. Water can't be returned to the height from which it falls using only its own energy, nor ash, heat and $\mathrm{CO}_{2}$ reassembled into coal. That makes it all the more imperative to find cheap ways of clearing detritus out of the way so that costs can be saved. Any locomotive that is to go on pulling railway coaches has to be provided with a place to vent its smoke, and workers to scrub it free of soot. Every Google translation machine needs dedicated, cheap living human or non-human activity to clear away the debris it generates, whether it be carbon dioxide or inappropriate word sequences.

But usable energy can become "waste" also just by being allowed to lie around unused. For example, the "falls" of river systems that are not exploited with hydroelectric dams that "break" the falls become viewed by technocratic organizations such as the Mekong River Commission as "wasted resources", much to the bemusement of communities that have depended on them for generations. Other wastes emerge after the dams are built and the reservoirs behind them silt up, removing the "fall" and necessitating dredging that must be powered via the exploitation of 
further "falls" elsewhere. Even the space that a quiet lake occupies can suddenly start looking like "waste" when the lake's energy is revealed to be "unusable". Insofar as thermodynamic energy amounts to a running modification of landscapes to exploit "falls" in pursuit of a good structured as unlimited (Hornborg 2001), it is also a shorthand for the unlimited expansion of the frontiers of degradation. It is not so much that the need for thermodynamic energy necessitates the physical and political re-engineering of territories. In a more elegant formulation, thermodynamic energy is the re-engineering of territories.

This "denaturalization" of the history of energy (Bonneuil and Fressoz 2016, p. 64) helps us understand thermodynamic propositions not only as valid science, but also as chunks of political ideology. For example, as the literary historian and physicist Barri Gold (2010, p. 9) observes, the Second Law idea that the amount of energy "beyond our use" tends to increase in a closed system can't escape questions such as: "What use? And who's we?" That generically anthropomorphic "we" (GeorgescuRoegen 1975, p. 351) would be unlikely to include indigenous peoples for whom what physicists would call the "unavailable" or "disordered" energy in a calm lake is far from useless, or peasants who deny that the energy in a fast-flowing river is "wasted" unless converted into hydroelectricity. The reality, indeed, is that thermodynamics tends to hide a vast, churning, enduring "underground" of anti-thermodynamic energies. These energies are around us always and everywhere, in cities as well as rural areas, in hospitals and factories as well as irrigation systems. Examples include the growth of vegetables in contemporary urban gardens in Milwaukee; the burning of commons firewood in Chiang Rai; or the bubbling of springs in the water-hill-village systems of Totonac communities in the Sierra Norte de Puebla (Smith 2007). The logic of such energies militates against aggregating them with one another and disentangling them from the limited goods of subsistence in the manner of the First Law of Thermodynamics. It also militates against becoming overly preoccupied with the Second Law, whose barrier to a notional "ideal efficiency" is more of an object of dread to capitalist technocrats and ecological modernizers than to ordinary people.

For millions of individuals virtually all of the time, and for everybody at least some of the time, periodically refusing thermodynamic 
energy's claim to be able to subsume anti-thermodynamic energies into itself is just a matter of common sense and survival. So, too, is keeping at arm's length thermodynamic projects featuring relentlessly mounting levels of disorder and waste that require professional management and concealment. Many rural areas worldwide reveal living retorts to such projects in the form of homely ways of working the vernacular wastes of commons - as when food waste is integrated into animal-raising, animal waste into field care and plant waste, cleaned up and recycled through fire, into the care of grain, forests, water and humans alike. From a subsistence perspective, such practices are not "renewable energy". They are not energy at all. They do not exemplify efficiency and are not productive of anything except themselves.

In fact, it is only when the heat source (the frontier of "usable energy") for the industrial engines that thermodynamics has worked to improve becomes a real abstraction that the heat sink (the zone of degraded energy or high "entropy") becomes a capitalist obsession and a global environmental issue. An ordinary rural community striving to take care of a local stream that never runs dry is typically not preoccupied with Wilhelm Ostwald's thermodynamically inspired "energetic imperative" — "do not waste any energy, make it useful” (Ostwald 1912, p. 85)—nor Nicholas Georgescu-Roegen's (1971) similarly motivated Malthusian cautions. For such a community, the Second Law is not necessarily a problem, any more than a perpetual motion machine that overcomes the Second Law is a shimmering "sublime object of ideology" (Žižek 1989). Nor would there be any point in praising such a community for "efficiency". Efficiency as understood today, riven by some of the same deep contradictions that afflict capital and thermodynamics (Polimeni et al. 2008), derives from a different context, that of industrial machines and their interpolation into societies organized around limitless accumulation.

The irony is-and this is an insight that is unfortunately missing from nearly all current global energy and climate debates, including debates over bioenergy and the so-called energy transition-that antithermodynamic energies are not only ubiquitous, but also, paradoxically, essential to maintaining the precarious status of thermodynamic energy itself. Together, the two form a "contradictory unity" (Harvey 2014) analogous to those that uneasily link living with dead labour, use value 
with exchange value, unpaid reproductive work with wage labour, and commons with capitalist forms of socio-natural organization. Unavoidably, "inside" the monolith of official energy can always be found a "hidden abode" (Fraser 2014) inhabited by a plurality of vernacular energies that it converts, commensurates, parasitizes, degrades and exhausts, yet which through their very opposition make it possible to accumulate surplus value (Toscano 2018). To capitalist planners, for example, a common woodland may at first sight look like either raw material for thermodynamic energy or an obstacle to be eliminated to make way for a hydroelectric dam, oil refinery or wind farm that produces more of it. Yet when economic crises hit and the planners themselves face redundancy, they may suddenly find themselves "recognizing" the woodland's nonthermodynamic energies as a useful zero-cost subsidy that helps maintain local workers pending their re-employment in the service of machines powered by thermodynamic energy. Or the planners may find themselves paradoxically dependent on the creative subversion that commoners exercise by thieving grid electricity to sustain subsistence systems dedicated to thwarting the commensuration of "little-e" energies into thermodynamic energy. In practice, it is only in conjunction with non-energetic, non-entropic or "negentropic" (Schrodinger 1944) enclaves in commons and elsewhere that the massively energetic, massively entropic machines reliant on thermodynamic energy become capable of working for capital for any significant length of time.

To put it another way, thermodynamic energy did not emerge once and for all in the nineteenth century. It continues to emerge in tandem with frontiers of resistance to its dominance. With a bit of patience, this resistance can be recognized in every kitchen, back garden, slum and factory floor. It can be glimpsed in every social movement fighting mining operations or even just local rights of way that highways catering to internal combustion engines threaten to break up. Thermodynamic energy is always under construction, but also always being undone, in millions of locations. Struggles contesting it form one part of continuing battles against enclosure of all kinds, including the dominance of the concept of resources. Any political struggle whose horizons extend beyond correcting prices, improving efficiency and securing wage work 
towards confronting patriarchy, racism, coercive capitalist social relations, commodity fetishism and capitalist work itself is likely eventually to find itself joining in already-existing movements confronting the hegemony of thermodynamic energy (Ediciones Inéditos 2019; Daggett 2019). So will any climate movement that seeks to build solidarity with workers, peasants and indigenous peoples struggling against oil extraction or bioenergy plantations instead of trying somehow to ally itself with "physics" against a generic class of human carbon dioxide emitters (Davis 2019; Invernizzi-Accetti 2019). As Christophe Bonneuil and Jean-Baptiste Fressoz (2016, p. 63) emphasize, any serious response to the "shock of the anthropocene" will need, in a sense, to "free itself from [...] the very concept of energy" and the "project that brings every form of work (from brain to blast furnace) into a generalized equivalence".

Like many other political projects of "masterful" abstraction, thermodynamic energy has a particular gender (Lutz 1995), a particular racial "colour" (Eze 1997; Dabashi 2015) and a particular class. It bears a bias against the practices of many oppressed groups accustomed to showing respect for a fire, a stream or a tool as "one of us" (Lenkersdorf 2008). And it sets its face against societies for whom "our history is the future" (Estes 2019) insofar as it superimposes the one-dimensional arrow of time of the Second Law of Thermodynamics on spiral or multidimensional time (Cusicanqui 2015), in which present and past events can be simultaneous or mutually embodied in one another (Anderson 2006, pp. 22-36). Like the frequent white feminist failure to interrogate race, or the common failure of antiracism to interrogate patriarchy (Crenshaw 1989), any failure of liberation movements to interrogate thermodynamic oppression is bound to reinforce the subordination and unequal status of peasants, workers, women, indigenous peoples and the colonized everywhere. 


\subsection{Bioenergy as Thermodynamic Energy: Deepening the Contradictions}

As is obvious from the other chapters in this book, adding the prefix "bio-" to energy changes nothing about its essential ecological and political characteristics. Bioenergy - in the sense used in this volume-is not an uncommensurating of the "little-e energies" referred to above nor a re-embedding of them in diverse commons practices. Nor is it a revalorization of non-energy-mediated relations among human beings and the more-than-human. That path is blocked by the angel with the flaming sword. Instead, bioenergy is thermodynamic energy and remains subject to all its contradictions. Opening a new chapter in the co-evolution of fossil-fuel dependence and thermodynamics, bioenergy is provoking a new phase of the same anti-colonial and anti-capitalist struggles that were modified so decisively by the development of energy itself.

Bioenergy's challenge to coal, oil and gas, in short, is purely notional. Bioenergy demands that living biomass supplement and substitute for fossil biomass as precisely the same kind of "universal fuel" that thermodynamics helped make possible. Its claim to be a fossil-free thermodynamic energy is a delusional denial of that energy's very fossil inheritance. Far from confining itself to enlisting living plant matter to round out the low-cost self-provisioning of reserve and other armies of labour, bioenergy policy indeed jams it ever more forcibly down onto the painful Procrustean bed of industrial capital's thermodynamic abstractions. Four hundred times more forcibly, in fact, given that capital has long been committed to appropriating the thermodynamic "equivalent" of at least 400 years of current plant growth in the form of fossil fuels for every year it continues to exploit human labour (Dukes 2003), and is now asking living biomass to help it, per impossibile, to strive for the same objective.

Take, for instance, the aviation industry, which is attempting to treat living biomass as if it were fossil fuel in two different ways. First, aviation biofuels are supposed to be able to "substitute" for kerosene, in spite of the fact that an area of land equivalent to that of a mediumsized country would have to be found and permanently set aside to grow plant fuels thermodynamically capable of replacing aviation's share of world petroleum consumption, and in spite of the tremendously 
entropic follow-on effects. Second, fossil carbon emissions from aviation are supposed to be able to be "offset" by yearly plant growth under the Carbon Offsetting and Reduction Scheme for International Aviation (CORSIA). This would require the annexation of land areas of the same order of magnitude again, together with the maximal formal and real subsumption of what is now called the "organism performance" of the most carbon-productive plant species and the ecosystems and human communities that are recrafted, degraded and progressively exhausted for the sake of their cultivation. This intensified dynamic of thermodynamic enclosure is likely to have similar outcomes at the grassroots whether it is impelled by environmental regulation or by efforts to transform biofuels, carbon offsets or biopatents into commodities, assets, claims on rent or objects for financial speculation-or by all of the above.

Arguably, that places today's battles against bioenergy projects at the very forefront of the two-century-old struggle resisting the dominion of thermodynamic energy. The experience of-for example-the Indonesian oil palm plantation worker in Malaysia or Indonesia (see Janina Puder and Hariati Sinaga in this volume) lies at the intersection (Crenshaw 1989) of multiple oppressions: landlessness, subjection to machine discipline, precaritization, externalization of reproduction costs, nation, patriarchy, race, class_-but now also the expanded hegemony of nineteenth-century thermodynamic energy, as increasing amounts of biomass are pressed into service as substitutes for energy-dense hydrocarbons. The Indonesian woman migrant in Malaysia cannot be spoken for by the male plantation worker, nor by the Indonesian peasant woman, nor by the formally educated Northern critic of thermodynamics, nor by a committee of the three. Yet while only she can say "when and where she enters" onto a path of liberation (ibid., p. 160), it is also true that only with her entry along that path that others struggling with thermodynamic energy can also enter.

In their analysis of the "biofuel delusion", Mario Giampietro and Kozo Mayumi (2009) conclude that

we do not need alternative energy sources to keep alive an obsolete pattern of economic growth. What we need is an alternative pattern of 
development that will make it possible to use alternative energy sources. (pp. 256-257)

This chapter has sought to go a step or two further still, by exposing the contradictions inherent in the very act of treating cane ethanol, wood pellets or aviation biofuel as energy, as well as by asking whether it is worth even talking about an "energy transition" that does not challenge the dominance of thermodynamics itself. A strategically effective critique of bioenergy developments has to go all the way down into energy itself.

One last way of summarizing the lesson of this chapter is to note the sense in which all bioenergy developments inherently entail the intensification of what this book's title refers to as "global inequalities". At a time when debates about energy equality are still overwhelmingly concerned only about the distribution of energy and of the costs of its production and circulation, it is more important than ever to stress that the prior issue is actually the constitution of energy. In a sense, inequalities are what thermodynamic energy is for. It should surprise no one that access to electricity, heat and motive power remains so skewed throughout the world, nor that so many have to suffer to make energy available to so few. From its beginning, thermodynamics has been a mode of denying practices that hundreds of millions of people depend upon to flourish and subsist. It is an integral part of a political settlement achieved and precariously maintained since the nineteenth century under which frontiers of appropriation are organized to make it possible for fossil capital to go on getting something for nothing from a commons both human and extrahuman (Moore 2015). Global inequalities connected with bioenergy development and energy transitions can't begin to be seriously addressed without addressing energy itself.

Acknowledgements Thanks for help to Simon Pirani, Nick Hildyard, Ivonne Yanez, Maria Backhouse, Fabricio Rodríguez and the Junior Research Group on Bioeconomy and Inequalities at Friedrich Schiller University, Jena, where another version of this paper was presented. 


\section{References}

Alexander, J.K. (2008). The Mantra of Efficiency: From Waterwheel to Social Control. Baltimore: Johns Hopkins University Press.

Anderson, B. (2006). Imagined Communities (revised edition). London: Verso. Bonneuil, C., \& Fressoz, J.-B. (2016). The Shock of the Anthropocene: The Earth, History and Us. (Trans.: Fernbach, D.). London: Verso.

Bridgman, P.W. (1943). The Nature of Thermodynamics. Cambridge: Harvard University Press.

Cardwell, D.S.L. (1993). Steam Engine Theory in the 19th Century: From Duty to Thermal Efficiency; from Parkes to Sankey. Transactions of the Newcomen Society, 65(1), 117-128.

Carnot, S. (1988 [1824]). Reflections on the Motive Power of Fire (Trans.: Thurston, R.H.). Ed. with an Introduction by Mendoza, E. Mineola: Dover. Coelho, R.L. (2009). On the Concept of Energy: History and Philosophy for Science Teaching. Procedia Social and Behavioral Sciences, 1, 2648-2652.

Crenshaw, K. (1989). Demarginalizing the Intersection of Race and Sex: A Black Feminist Critique of Antidiscrimination Doctrine, Feminist Theory and Antiracist Politics. University of Chicago Legal Forum, 1, 138-167.

Cusicanqui, S.R. (2015). Sociología de la imagen: Miradas ch’ixi desde la historia andina. Buenos Aires: Tinta Limón.

Dabashi, H. (2015). Can Non-Europeans Think? London: Zed Books.

Daggett, C.N. (2019). The Birth of Energy: Fossil Fuels, Thermodynamics and the Politics of Work. Durham: Duke University Press.

Davis, D. (2019, April 16). Climate Change Is 'Greatest Challenge Humans Have Ever Faced,' Author Says. National Public Radio. https://www.npr. org/2019/04/16/713829853/climate-change-is-greatest-challenge-humanshave-ever-faced-author-says. Accessed 12 Jan 2020.

Deacon, T.W. (2011). Incomplete Nature: How Mind Emerged from Matter. New York: Norton.

Dukes, J.S. (2003). Burning Buried Sunshine: Human Consumption of Ancient Solar Energy. Climatic Change, 61, 31-44.

Ediciones Inéditos (2019). Prole Wave: Climate Change, Circulation Struggles and the Communist Horizon. Non.copyriot.com. https://non.copyriot.com/ prole-wave-climate-change-circulation-struggles-the-communist-horizon/. Accessed 12 Jan 2020. 
Estes, N. (2019) Our History Is the Future: Standing Rock Versus the Dakota Access Pipeline, and the Long Tradition of Indigenous Resistance. London: Verso.

Eze, E.C. (1997). The Color of Reason: The Idea of "Race" in Kant's Anthropology. In E.C. Eze (Ed.), Postcolonial African Philosophy: A Critical Reader (pp. 103-140). Oxford: Blackwell.

Feynman, R. (2010). The Feynman Lectures on Physics. Vol. 1. New York: Basic.

Fraser, N. (2014). Behind Marx's Hidden Abode: For an Expanded Concept of Capitalism. New Left Review, 86, 55-72.

Georgescu-Roegen, N. (1975). Energy and Economic Myths. Southern Economic Journal, 41(3), 347-381.

Georgescu-Roegen, N. (1971) The Entropy Law and the Economic Process. Cambridge: Harvard University Press.

Giampietro, M., \& Mayumi, K. (2009). The Biofuel Delusion: The Fallacy of Large-Scale Agro-Biofuel Production. London: Earthscan.

Gold, B.J. (2010). ThermoPoetics: Energy in Victorian Literature and Science. Cambridge: The MIT Press.

Harvey, D. (2014). Seventeen Contradictions and the End of Capitalism. Oxford: Oxford University Press.

Hornborg, A. (2001). The Power of the Machine: Global Inequalities of Economy, Technology and Environment. Walnut Creek: Altamira.

Huber, M. (2009). Energizing Historical Materialism: Fossil Fuels, Space and the Capitalist Mode of Production. Geoforum, 40(1), 105-115.

Invernizzi-Accetti, C. (2019, December 29). Climate Change Denial May Have Been Defeated in 2019, but What Comes Next Won't Be Easier. The Guardian. https://www.theguardian.com/commentisfree/2019/dec/29/theclimate-movement-is-about-to-get-more-political-and-thats-a-good-thing. Accessed 22 Oct 2020.

Lenkersdorf, C. (2008). Aprender a escuchar: Enseñanzas maya-tojolabales. Mexico D.F.: Plaza y Valdés.

Lohmann, L., \& Hildyard, N. (2014). Energy, Work and Finance. Sturminster Newton: The Corner House. http://www.thecornerhouse.org.uk/sites/the cornerhouse.org.uk/files/EnergyWorkFinance\%20\%282.57MB\%29.pdf. Accessed 22 Oct 2020.

Lutz, C. (1995). The Gender of Theory. In R. Behar \& D.A. Gordon (Eds.), Women Writing Culture (pp. 249-266). Berkeley: University of California Press.

Malm, A. (2016). Fossil Capital: The Rise of Steam Power and the Roots of Global Warming. London: Verso. 
Mirowski, P. (1989). More Heat Than Light: Economics as Social Physics, Physics as Nature's Economics. Cambridge: Cambridge University Press.

Mokyr, J. (1999). Editor's Introduction: The New Economic History and the Industrial Revolution. In J. Mokyr (Ed.), The British Industrial Revolution: An Economic Perspective (pp. 1-127). Boulder: Westview.

Moore, J. (2015). Capitalism in the Web of Life: Ecology and the Accumulation of Capital. London: Verso.

Nalepa, R.A., \& Bauer, D.M. (2012). Marginal Lands: The Role of Remote Sensing in Constructing Landscapes for Agrofuel Development. Journal of Peasant Studies, 39(2), 403-422.

National Academy of Sciences [US] (1974). Rehabilitation Potential of Western Coal Lands: A Report to the Energy Policy Project of the Ford Foundation. Cambridge: Ballinger.

Ostwald, W. (1912). Der energetische Imperativ. Leipzig: Akademische Verlagsgesellschaft.

Polimeni, J.M., Mayumi, K., Giampietro, M., \& Alcott, B. (2008). The Jevons Paradox and the Myth of Resource Efficiency Improvements. London: Earthscan.

Pomeranz, K. (2000). The Great Divergence: China, Europe, and the Making of the Modern World Economy. Princeton: Princeton University Press.

Porter, T.M. (1994). Rigour and Practicality: Rival Ideals of Quantification in Nineteenth-Century Economics. In P. Mirowski (Ed.), Natural Images in Economic Thought (pp. 128-170). Cambridge: Cambridge University Press. Sakai, N. (1997). Translation and Subjectivity: On Japan and Cultural Nationalism. Minneapolis: University of Minnesota Press.

Schrodinger, E. (1944). What Is Life? Cambridge: Cambridge University Press.

Sieferle, R. (2010 [1982]). The Subterranean Forest: Energy Systems and the Industrial Revolution. Cambridge: The White Horse Press.

Smil, V. (2017). Energy and Civilization: A History. Cambridge: The MIT Press.

Smith, C., \& Wise, M.N. (1989). Energy and Empire: A Biographical Study of Lord Kelvin. New York: Cambridge University Press.

Smith, W.D. (2007). Presence of Mind as Working Climate Change Knowledge: A Totonac Cosmopolitics. In M. Pettenger (Ed.), The Social Construction of Climate Change: Power, Knowledge, Norms, Discourses (pp. 217-234). Aldershot: Ashgate.

Steffen, W., Grinevald, J., Crutzen, P., \& McNeill, J. (2011). The Anthropocene: Conceptual and Historical Perspectives. Philosophical Transactions of the Royal Society A, 369, 842-867. 
Toscano, A. (2018). Antiphysis/Antipraxis: Universal Exhaustion and the Tragedy of Materiality. In B.R. Bellamy \& J. Diamanti (Eds.), Materialism and the Critique of Energy (pp. 471-499). Chicago: MCM Publishing.

Wrigley, E.A. (2010). Energy and the English Industrial Revolution. Cambridge: Cambridge University Press.

Žižek, S. (1989). The Sublime Object of Ideology. London: Verso.

Open Access This chapter is licensed under the terms of the Creative Commons Attribution 4.0 International License (http://creativecommons.org/ licenses/by/4.0/), which permits use, sharing, adaptation, distribution and reproduction in any medium or format, as long as you give appropriate credit to the original author(s) and the source, provide a link to the Creative Commons license and indicate if changes were made.

The images or other third party material in this chapter are included in the chapter's Creative Commons license, unless indicated otherwise in a credit line to the material. If material is not included in the chapter's Creative Commons license and your intended use is not permitted by statutory regulation or exceeds the permitted use, you will need to obtain permission directly from the copyright holder. 